\title{
Hormones Regulate in Vitro Organ Regeneration from Leaf-Derived Explants in Arabidopsis
}

\author{
Xiangyu Zhao*, Guoting Liang*, Xingguo Li, Xiansheng Zhang\# \\ State Key Laboratory of Crop Biology, Shandong Key Laboratory of Crop Biology, College of Life Sciences, \\ Shandong Agricultural University, Taian, China \\ Email: "zhangxs@sdau.edu.cn
}

Received 20 September 2014; revised 19 October 2014; accepted 7 November 2014

Copyright (C) 2014 by authors and Scientific Research Publishing Inc.

This work is licensed under the Creative Commons Attribution International License (CC BY).

http://creativecommons.org/licenses/by/4.0/

(c) () Open Access

\section{Abstract}

Plant in vitro organogenesis is well-controlled and thus provides an ideal system for plant propagation and studying mechanisms of plant development. However, the data on systematic in vitro organogenesis from leaf explant with various concentrations and combinations of hormones are limited. Arabidopsis is a very useful model plant species for many aspects of plant biological study. Here, we reported a simple, fast and efficient one-step process for evaluating leaf explant-derived in vitro Arabidopsis organogenesis involving the application of various concentrations and combinations of exogenous hormones. The central portion of the fourth rosette leaf was harvested from the 21-days-old seedling and cultured in vitro on the media containing 216 combinations of exogenous hormones. Different types of organs, including roots, shoots, inflorescences, and leaflike organs were initiated from leaf explants. Several optimal experimental combinations were selected. A hormone combination, $1.00 \mu \mathrm{M} N A A+10.00 \mu \mathrm{M} \mathrm{ZT}$, was considered as the most efficient one for adventitious shoot regeneration. And for adventitious root regeneration, six hormone combinations, [(NAA + ZT: $1.00+0.10 \mu \mathrm{M} ; 10.00+0.01 \mu \mathrm{M} ; 20.00+0.10 \mu \mathrm{M} ; 20.00+1.00$ $\mu \mathrm{M})$ and (NAA + 6-BA: $10.00+0.10 \mu \mathrm{M} ; 20.00+10.00 \mu \mathrm{M})]$, were thought to be the best ones. Further, both auxin and cytokinin ratios and concentrations were crucial for efficient in vitro organogenesis. Our study provides the important information for hormone-regulated organogenesis.

\section{Keywords}

Arabidopsis, Hormones, In Vitro Organogenesis, Leaf

\footnotetext{
*These authors contributed equally to this work.

${ }^{\#}$ Corresponding author
}

How to cite this paper: Zhao, X.Y., Liang, G.T., Li, X.G. and Zhang, X.S. (2014) Hormones Regulate in Vitro Organ Regeneration from Leaf-Derived Explants in Arabidopsis. American Journal of Plant Sciences, 5, 3535-3550. 


\section{Introduction}

Plant cells, organs and tissues exhibit a remarkable ability to regenerate new organs under in vitro conditions [1]. Various types of organs, including vegetative and reproductive organs, have been successfully regenerated from hundreds of plant species [2]-[8]. Thus far, in vitro somatic organogenesis has not only been widely used in plant propagation and plant biotechnology, but also has been proven to be an important system for investigating mechanisms of plant organ development [9].

Exogenous hormones are widely regarded as being more important than other factors [10]-[18]. Auxin and cytokinin are critical for the regulation of organ regeneration, with the concentration ratio between these hormones determining the specific types of regenerated organs, such as shoots or roots [19] [20]. However, the specific roles of different concentrations and/or combinations of auxin and cytokinin during organogenesis remain to be investigated.

It has been shown that in some plants semi-mature and fully developed leaves gave good response of shoot organogenesis in vitro [21]-[25]. The advantages of using leaves from in vitro seedlings lie in the abundant supply of explants and a lower risk of contamination. Leaf discs have been successfully employed as starting explants for Agrobacterium-mediated transformation in several plant species [26] [27].

Arabidopsis is a very useful model plant species for developmental studies, biological investigations and genetic engineering due to its unique genetic and developmental characteristics. Recent advances in genetic and molecular techniques, combined with unique approaches to tissue culture, may provide new insights into the mechanism underlying many fundamental biological activities such as cell dedifferentiation, cell developmental fate determination and intercellular communication [28]. To our knowledge, current data on systematic in vitro organogenesis from different types of Arabidopsis explants under the regulation of various concentrations and combinations of auxin and cytokinin have been limited.

In this study, we describe a simple, fast and efficient one-step process for organogenesis from leaf-derived callus and present the effects of various concentrations of exogenous hormones on in vitro organogenesis in Arabidopsis. In our previous work, the one-step process for in vitro organ regeneration had been developed and defined [29]. This newly developed in vitro organ regeneration system will be useful for more efficient organ regeneration and for understanding hormone-regulated organogenesis.

\section{Materials and Methods}

\subsection{Plant Materials and Culture Conditions}

Arabidopsis Wassilewskija-0 (WS-0) (Provided by the Arabidopsis Biological Resource Center) ecotype seeds were surface sterilized with $70 \%(\mathrm{v} / \mathrm{v})$ ethanol for 5 min followed by $2.6 \%(\mathrm{v} / \mathrm{v})$ commercial bleach with a drop of tween-20 (Sigma-Aldrich) for $10 \mathrm{~min}$, and then washed four times with sterile $\mathrm{dd}_{2} \mathrm{O}$ prior to plating on half-strength Murashige and Skoog (MS) medium (Sigma-aldarich, pH5.8, $1 \mathrm{~L}$, consisting of $0.825 \mathrm{~g} \mathrm{NH}_{4} \mathrm{NO}_{3}$, $0.95 \mathrm{~g} \mathrm{KNO}_{3}, 0.22 \mathrm{~g} \mathrm{CaCl}_{2} \cdot 2 \mathrm{H}_{2} \mathrm{O}, 0.185 \mathrm{~g} \mathrm{MgSO}_{4} \cdot 7 \mathrm{H}_{2} \mathrm{O}, 0.085 \mathrm{~g} \mathrm{KH}_{2} \mathrm{PO}_{4}, 0.83 \mathrm{mg} \mathrm{KI}, 6.2 \mathrm{mg} \mathrm{H}_{3} \mathrm{BO}_{3}, 22.3 \mathrm{mg}$ $\mathrm{MnSO}_{4} \cdot 4 \mathrm{H}_{2} \mathrm{O}, 8.6 \mathrm{mg} \mathrm{ZnSO} \cdot 7 \mathrm{H}_{2} \mathrm{O}, 0.25 \mathrm{mg} \mathrm{Na} \mathrm{MoO}_{4} \cdot 2 \mathrm{H}_{2} \mathrm{O}, 0.025 \mathrm{mg} \mathrm{CuSO} \cdot \cdot 5 \mathrm{H}_{2} \mathrm{O}, 0.025 \mathrm{mg} \mathrm{CoCl} \cdot 6 \mathrm{H}_{2} \mathrm{O}$, $37.3 \mathrm{mg} \mathrm{FeSO} \cdot 7 \mathrm{H}_{2} \mathrm{O}, 27.8 \mathrm{mg} \mathrm{Na} 2$-EDTA $2 \mathrm{H}_{2} \mathrm{O}, 100 \mathrm{mg}$ inositol, $0.1 \mathrm{mg} \mathrm{VB}, 0.5 \mathrm{mg} \mathrm{VB}$, $0.5 \mathrm{mg} \mathrm{VB}$, 2.0 mg glycine. Murashige and Skoog, 1962) [30] supplemented with $3 \%(\mathrm{w} / \mathrm{v})$ sucrose and $0.8 \%(\mathrm{w} / \mathrm{v})$ gelrite (sigma-aldarich, G1910). The plates were incubated at $4^{\circ} \mathrm{C}$ in darkness for two days to overcome dormancy, and then maintained at typical tissue culture conditions $\left(20^{\circ} \mathrm{C}-22^{\circ} \mathrm{C}, 16 \mathrm{~h} \mathrm{light} / 8 \mathrm{~h}\right.$ darkness $)$. The seedlings were allowed to grow for 7 days and then were sub-cultured on the same medium in $250 \mathrm{~mL}$ flasks under the same conditions for 14 days. When the fourth rosette leaf reached half its full length, the central portion was harvested and organ induction was stimulated using culture on the medium described as following. All experiments were repeated three times, and each experiment consisted of $>100$ explants.

The primary goal of this study was to characterize the effects of exogenous hormones on organogenesis initiated from leaf explants. Systematic changes in auxin and cytokinin concentrations were designed and used to establish a one-step approach for callus induction as well as organ regeneration. This one step approach includes the use of the MS basal medium (Sigma-aldarich, pH5.8, $1 \mathrm{~L}$, consisting of $1.65 \mathrm{~g} \mathrm{NH}_{4} \mathrm{NO}_{3}, 1.9 \mathrm{~g} \mathrm{KNO}_{3}, 0.44 \mathrm{~g}$ $\mathrm{CaCl}_{2} \cdot 2 \mathrm{H}_{2} \mathrm{O}, 0.37 \mathrm{~g} \mathrm{MgSO}_{4} \cdot 7 \mathrm{H}_{2} \mathrm{O}, 0.17 \mathrm{~g} \mathrm{KH}_{2} \mathrm{PO}_{4}, 0.83 \mathrm{mg} \mathrm{KI}, 6.2 \mathrm{mg} \mathrm{H}_{3} \mathrm{BO}_{3}$, $22.3 \mathrm{mg} \mathrm{MnSO}_{4} \cdot 4 \mathrm{H}_{2} \mathrm{O}, 8.6 \mathrm{mg}$ $\mathrm{ZnSO}_{4} \cdot 7 \mathrm{H}_{2} \mathrm{O}, 0.25 \mathrm{mg} \mathrm{Na} \mathrm{MoO}_{4} \cdot 2 \mathrm{H}_{2} \mathrm{O}, 0.025 \mathrm{mg} \mathrm{CuSO} \cdot 5 \mathrm{H}_{2} \mathrm{O}, 0.025 \mathrm{mg} \mathrm{CoCl} \cdot 6 \mathrm{H}_{2} \mathrm{O}, 37.3 \mathrm{mg} \mathrm{FeSO} \cdot{ }_{4} \cdot 7 \mathrm{H}_{2} \mathrm{O}$,

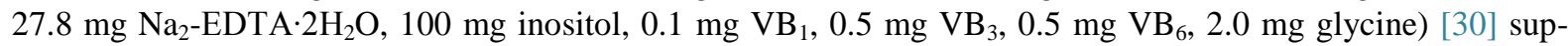


plemented with 3\% (w/v) sucrose, $0.8 \%(w / v)$ gelrite (sigma-aldarich, G1910) and various concentrations (0.00, $0.01,0.10,1.00,10.00,20.00 \mu \mathrm{M})$ of Zeatin (ZT) or 6-Benzylaminopurine (6-BA) in combination with 0.00 , $0.01,0.10,1.00,10.00,20.00 \mu \mathrm{M}$ Indole-3-acetic acid (IAA) or 1-Naphthaleneacetic acid (NAA) or 2,4-D, which results in 36 unique treatments listed in Table S1. Each experimental treatment consisted of three replicates of three Petri dishes with 20 explants in each dish. Two weeks later, the cultured explants were transferred to fresh media. Cultured explants undergoing callus induction and organ regeneration were maintained under the conditions of $25^{\circ} \mathrm{C} \pm 2{ }^{\circ} \mathrm{C}$ and a $16 / 8 \mathrm{~h}$ day/night photoperiod with $100 \mathrm{mmolm}{ }^{-2} \cdot \mathrm{s}^{-1}$ cool white fluorescent lamps.

The $\mathrm{pH}$ value of media mentioned above was adjusted to 5.8 using $\mathrm{pH}$ meter (UB-7, Denver Instrument Company, USA) before autoclaving for 20 minutes at $121^{\circ} \mathrm{C}, 105 \mathrm{kPa}$.

All kinds of hormones were produced by Sigma-Aldrich. One hundred milligram IAA (No. 12886), 2,4-D (D7299) or NAA (N0640) was dissolved in a small volume of ethyl alcohol, and then brought to $1 \mathrm{ml}$ with $\mathrm{ddH}_{2} \mathrm{O}$. For cytokinin, a few drops of $1 \mathrm{NaOH}$ were required to bring ZT (100 mg) or 6-BA (100 mg) into solution, and then $\mathrm{ddH}_{2} \mathrm{O}$ was added up to $100 \mathrm{ml}$. Filtration was required for ZT solution because it was considered to be unstable in the heat. The stock solutions of NAA and 2,4-D were stored at $4^{\circ} \mathrm{C}$, and IAA, ZT, and 6-BA were stored at $-20^{\circ} \mathrm{C}$.

\subsection{Light Microscopy}

Morphological observations of regenerated organs were conducted using an Olympus SZX16 stereo microscope (Olympus America Inc.). Microscopy images were captured using an Olympus DP72 digital camera (Olympus America Inc.).

\subsection{Data Analysis}

The frequency of callus induction and number of calli induced from explants was assessed at approximately experimental day 7. Evaluation of explant regeneration efficiency began after one to two weeks in culture. The parameters investigated in the present study include the regeneration frequency (\% of explants capable of organ regeneration under the present in vitro conditions) of adventitious shoots, inflorescences, leaf-like organs, and adventitious roots. Regeneration frequency was calculated as the percentage of explants capable of organ regeneration under the culture conditions described above. Equation is as following:

$$
\text { Organ Regeneration Frequency }=\frac{\text { Numbers of Calli Capable of Organs Regeneration }}{\text { total Number of Explants }} \times 100 \%
$$

Data collected from each of three replicate experiments were averaged and expressed as the mean \pm s.e.m.

\section{Results and Discussion}

\subsection{Leaf Explant-Derived Organ Regeneration}

Leaf explant-derived plant regeneration has been widely used for various studies conducted in many plant species [25] [26] [31] [32]. To further analyze the effects of concentrations of hormones and the combinations of various kinds of hormones on Arabidopsis organ regeneration, 216 combinations of exogenous hormones were designed (Table S1). We reported the capacity of the middle segment of the fourth rosette leaf in the 14-day-old seedling for leaf-derived organogenesis regulated by various hormone combinations (Figure 1(A)).

Efficient callus induction was observed on all sides of the wounded explant, especially on the midrib, within two weeks in culture (Figure 1(B)). Indeed, all four types of organogenesis (shoot, inflorescence, leaf-like structure, and adventitious root) were induced in vitro from leaf explants, as described above using root and inflorescence stem explants (Figures $1(\mathrm{C})-(\mathrm{F})$ ). Of these structures, adventitious root regeneration appeared to be most efficient with shoot regeneration second, whereas induction of inflorescences and leaf-like organs was less efficient (Table S2). The most efficient adventitious shoot regeneration obtained from leaf explants reached $80 \%$ under the optimal combination of hormones (1.00 $\mu \mathrm{M}$ NAA $+10.00 \mu \mathrm{M} \mathrm{ZT}$, Table S2 and Figure 2(E)).

Among the four types of regenerated organs from leaf explants, adventitious root regeneration was the most frequent. Leaf explants responded well to nearly $50 \%$ of the designed media containing various hormone combinations [(NAA + ZT: $1.00+0.10 \mu \mathrm{M} ; 10.00+0.01 \mu \mathrm{M} ; 20.00+0.10 \mu \mathrm{M} ; 20.00+1.00 \mu \mathrm{M})$ or $(\mathrm{NAA}+6-\mathrm{BA}$ : $10.00+0.10 \mu \mathrm{M} ; 20.00+10.00 \mu \mathrm{M})]$, generating the highest frequency $(100 \%)$ of adventitious root formation 

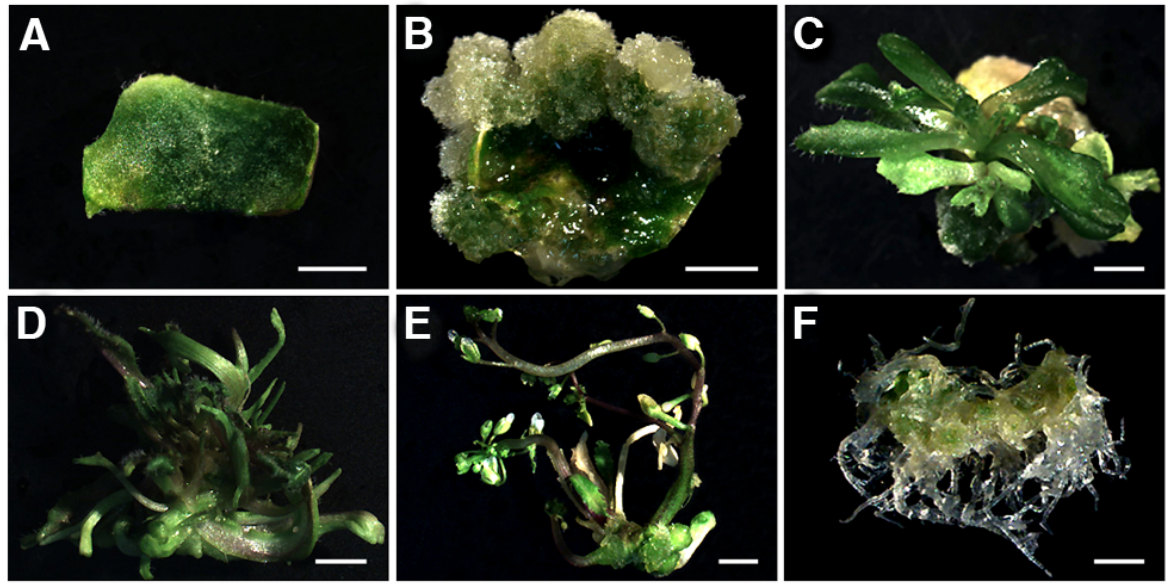

Figure 1. Leaf explant-derived organogenesis. (A) A leaf explant taken from the central part of the fourth rosette leaf of a 14-day-old seedling was cultured on MS medium containing various combinations of auxin and cytokinin; (B) Multiple calli were induced at the wounded sites of the explant, and in particular the midrib, after two weeks in culture; (C) Adventitious shoots regenerated from "B"; (D) Leaf-like organs; (E) inflorescences and (F) adventitious roots were also induced. Bars represent $40 \mu \mathrm{m}$.
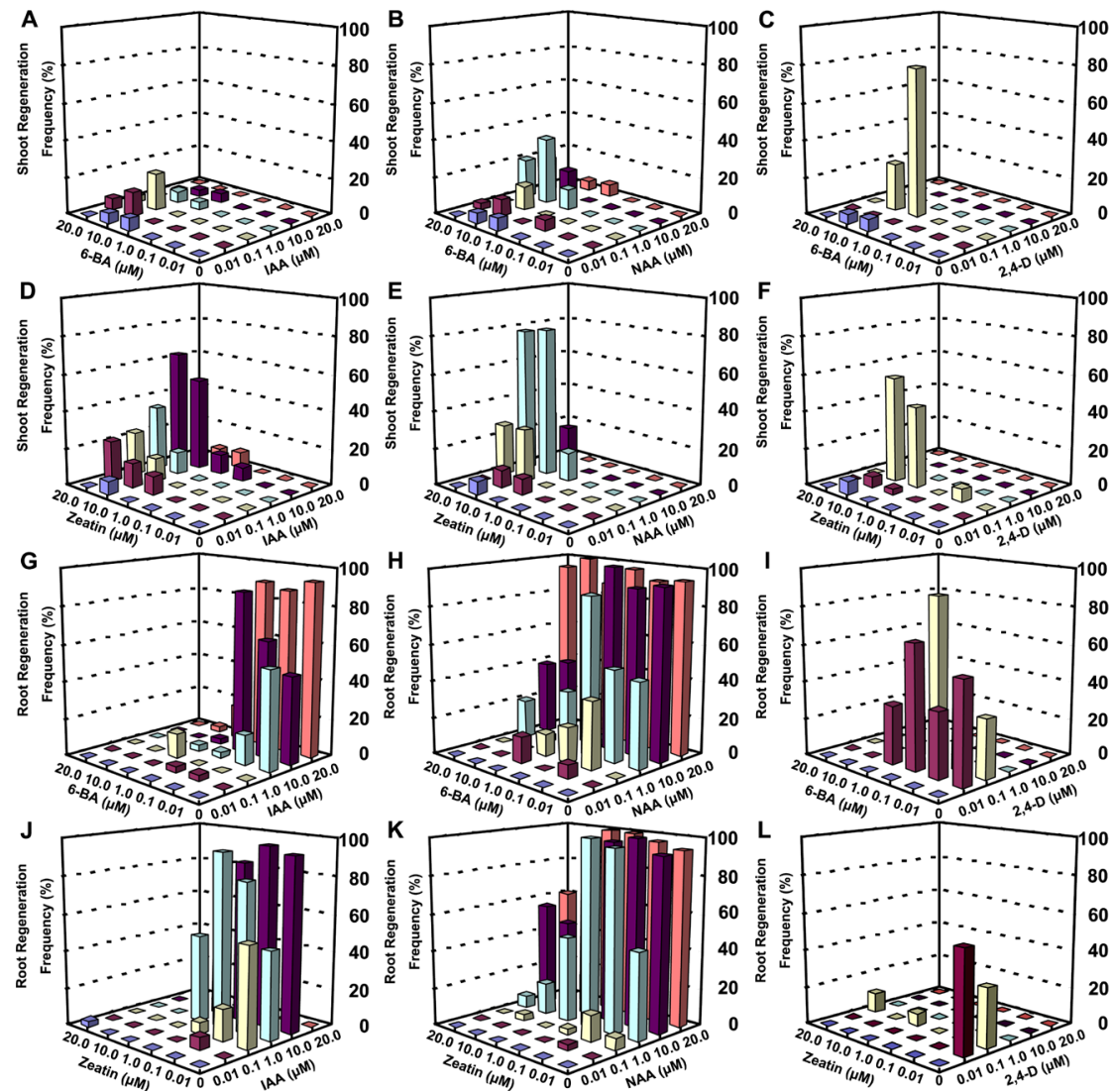

Figure 2. Variations in shoot and root regeneration from leaf explants following culture on media containing different hormone combinations. (A-F) Efficiency of shoot regeneration induced by multiple combinations and concentrations of (A) IAA + 6-BA, (B) NAA + 6-BA, (C) 2,4-D + 6-BA, (D) IAA + ZT, (E) NAA + ZT and (F) 2,4-D + ZT, respectively. (G-L) Efficiency of root regeneration induced by multiple combinations and concentrations of (A) IAA + 6-BA, (B) NAA + 6-BA, (C) 2,4-D + 6-BA, (D) IAA + ZT, (E) NAA + ZT and (F) 2,4-D + ZT, respectively. The histograms were created using Microsoft Excel software. The bar colors indicate different auxin concentration lines (Dark blue, $0.00 \mu \mathrm{M}$; Red, $0.01 \mu \mathrm{M}$; Yellow, $0.10 \mu \mathrm{M}$; Powder blue, $1.00 \mu \mathrm{M}$; Purple, $10.00 \mu \mathrm{M}$; Orange, $20.00 \mu \mathrm{M})$. 
(Table S2; Figure 2(H) and Figure 2(I)). The high efficiency of adventitious root induction via leaf explants may have potential applications in horticulture and agronomy, especially for crops with difficult in vivo rooting capability [33].

\subsection{Both Concentration and Ratio of Exogenous Cytokinin to Auxin Are Critical during in Vitro Organogenesis}

In the present study, different organ types were induced from explants with varying frequency, depending on the culture conditions (Figure 2; Table 1 and Table S2). Among these regenerated organs, shoots and roots are the most important organs for plant micropropagation. Thus, the frequencies of shoot and root organogenesis were further analyzed (Figure 2). Results indicate that the auxin-to-cytokinin ratio has significant effects on shoot and root regeneration (Table 2), with a low ratio of auxin to cytokinin inducing the maximum frequency of shoot regeneration. Shoots can also be induced with variable frequency on the intermediate, even lower, auxinto-cytokinin ratio combination. A clearly similar trend was also observed with regard to the efficiency of adventitious root regeneration (e.g., $20.00 \mu \mathrm{M}$ NAA plus $20.00 \mu \mathrm{M}$ 6-BA for leaf explants), with the exception of a requirement for a higher auxin concentration (Figure 2; Table S2). Our data indicate that the exogenous hormone ratio is not the only critical factor, and that other factors such as hormone concentrations might be equally important for efficient shoot and root induction. Hence, it is likely that the fine-tuned balance between hormone ratio and hormone concentration is required for cell fate determination, which supports the need for detailed studies investigating the effects of various concentrations of hormones on in vitro organogenesis.

To address this topic, six concentrations per hormone were devised in order to determine the best concentration range based on the response of explant cells. As shown in Figure 3, there were significant differences among the optimal concentration ranges for different hormones administered for adventitious shoot and root regeneration. In general, the optimal auxin concentration for inducing the most effective shoot formation from all three types of explants was lower than that for adventitious root regeneration (Figures 3(A)-(F)), whereas the effective cytokinin concentration for shoot induction was higher than that for adventitious root formation (Figures 3(G)-(J)).

Optimal concentrations of IAA for effective shoot induction ranged from 0.01 to $1.00 \mu \mathrm{M}$, followed by optimal concentrations of NAA $(0.01$ to $20.00 \mu \mathrm{M})$ and 2,4-Dichlorophenoxyacetic acid (2,4-D) $(0.01-1.00 \mu \mathrm{M})$. High shoot regeneration frequency occurred when these were combined with 1.00 to $20.00 \mu \mathrm{M}$ of 6-BA or with 0.10 to $20.00 \mu \mathrm{M}$ of ZT (Figure 3(A), Figure 3(C), Figure 3(E), Figure 3(G) and Figure 3(I)). Efficient adventitious root regeneration required either IAA or NAA over a similar concentration range (0.01 to $20.00 \mu \mathrm{M})$; however, a wider range of 2,4-D concentrations was found for adventitious root induction than for shoot regeneration (Figure 3(B), Figure 3(D), Figure 3(F), Figure 3(H) and Figure 3(J)). These data demonstrate that

\section{Table 1. In vitro organogenesis from Arabidopsis leaf explants.}

\begin{tabular}{|c|c|c|}
\hline Regenerated organs & & \\
\hline \multirow{2}{*}{ Shoots } & Mean $^{a}$ & 5.49 \\
\hline & Maximum $^{\mathrm{b}}$ & $80.00 \pm 4.58$ \\
\hline \multirow{2}{*}{ Inflorescences } & Mean $^{c}$ & 0.49 \\
\hline & Maximum $^{\mathrm{d}}$ & $55.30 \pm 2.65$ \\
\hline \multirow{2}{*}{ Leaf-like organs } & Mean $^{\mathrm{e}}$ & 1.56 \\
\hline & Maximum $^{\mathrm{f}}$ & $21.22 \pm 4.02$ \\
\hline \multirow{2}{*}{ Roots } & Mean $^{\mathrm{g}}$ & 21.89 \\
\hline & Maximum $^{\mathrm{h}}$ & $97.07 \pm 2.11$ \\
\hline
\end{tabular}

${ }^{\mathrm{a}}$ The number represents the mean arithmetical value of the frequencies of regenerated shoots. ${ }^{\mathrm{b}}$ The number represents the highest frequency of regenerated shoots. ${ }^{\mathrm{c}}$ The number represents the mean arithmetical value of the frequencies of regenerated inflorescences. ${ }^{\mathrm{d}}$ The number represents the highest frequency of regenerated inflorescences. ${ }^{\mathrm{e}}$ The number represents the mean arithmetical value of the frequencies of regenerated leaf-like organs. ${ }^{\mathrm{T}}$ The number represents the highest frequency of regenerated leaf-like organs. ${ }^{\mathrm{g}}$ The number represents the mean arithmetical value of the frequencies of regenerated roots. h The number represents the highest frequency of regenerated roots. 
Table 2. Hormone combinations suitable for regeneration of shoots or roots from Arabidopsis leaf explants

\begin{tabular}{|c|c|c|c|}
\hline Type of Regenerated organs & Combination (Auxin/CK) & Concentration $(\mu \mathrm{M})$ & Regenerated Frequency (\%) \\
\hline \multirow{6}{*}{ Shoots } & 2,4-D/6-BA & $0.10 / 10.00$ & $81.25 \pm 7.02$ \\
\hline & $2,4-\mathrm{D} / \mathrm{ZT}$ & $0.10 / 10.00$ & $91.30 \pm 5.70$ \\
\hline & IAA/6-BA & $0.10 / 10.00$ & $19.71 \pm 1.65$ \\
\hline & IAA/ZT & $10.00 / 20.00$ & $62.56 \pm 3.42$ \\
\hline & NAA/6-BA & $1.00 / 10.00$ & $35.78 \pm 2.54$ \\
\hline & NAA/ZT & $1.00 / 10.00$ & $80.00 \pm 4.58$ \\
\hline \multirow{10}{*}{ Roots } & 2,4-D/6-BA & $0.10 / 0.10$ & $88.25 \pm 5.34$ \\
\hline & 2,4-D/ZT & $0.01 / 0.00$ & $54.50 \pm 2.51$ \\
\hline & IAA/6-BA & $20.00 / 0.00$ & $93.34 \pm 2.74$ \\
\hline & IAA/ZT & $10.00 / 0.01$ & $96.65 \pm 0.86$ \\
\hline & NAA/6-BA & $10.00 / 0.10$ & 100.00 \\
\hline & NAA/6-BA & $20.00 / 10.00$ & 100.00 \\
\hline & NAA/ZT & $1.00 / 0.10$ & 100.00 \\
\hline & NAA/ZT & $10.00 / 0.01$ & 100.00 \\
\hline & NAA/ZT & $20.00 / 0.10$ & 100.00 \\
\hline & NAA/ZT & $20.00 / 1.00$ & 100.00 \\
\hline
\end{tabular}

both the hormone ratios and their concentrations are crucial for deter mining cell developmental fate during in vitro organogenesis.

\subsection{Hormone Type Affects Organ Regeneration}

In the present study, IAA (natural auxin) was the most efficient auxin, whereas 2,4-D (synthetic auxin) was the least effective auxin at inducing leaf explant-derived shoot regeneration (Figures 2(A)-(F)). A wide range of NAA (synthetic auxin) concentrations was capable of inducing adventitious roots at very high efficiencies compared to IAA and 2,4-D (Figure 2(H) and Figure 2(K)). In summary, these results indicate that efficient organ initiation depends largely on the type of auxin and the type of explant. The fact that NAA is more efficient than IAA and 2,4-D in triggering adventitious root initiation, but less effective than IAA in inducing shoot formation, implies that hormone requirements for shoot induction may be more complicated than requirements for adventitious root formation.

Another important observation revealed by the present study was that auxin alone could initiate callus and/or adventitious root formation and sometimes shoot formation from each of the three types of explants with variable induction rates (Figure 2). Treatment with IAA alone can induce adventitious shoots or roots, and NAA alone promotes root regeneration. For 2,4-D, soft and light yellowish callus can be developed, but not organ regeneration (Table S2). Current results also support the hypothesis that in vitro organogenesis can occur through exposure to exogenous auxin, which in turn triggers the biosynthesis of endogenous cytokinin [34]. Thus, the present data further suggest that exposure to exogenous auxin during in vitro organogenesis rapidly induces cytokinin biosynthesis. Moreover, the specific regulatory effects may depend on the specific type of auxin.

Additionally, this study has also demonstrated that the use of cytokinin (e.g., ZT or 6-BA) at a lower concentration efficiently induced adventitious root formation (Figures 2(G)-(L)). A similar finding has been reported by George et al. (2008) [35], who reported that high concentrations of cytokinin (0.5 - $10 \mathrm{mg} / \mathrm{l})$ generally inhibited or delayed root formation. However, in the present study, new shoots were efficiently induced at higher 

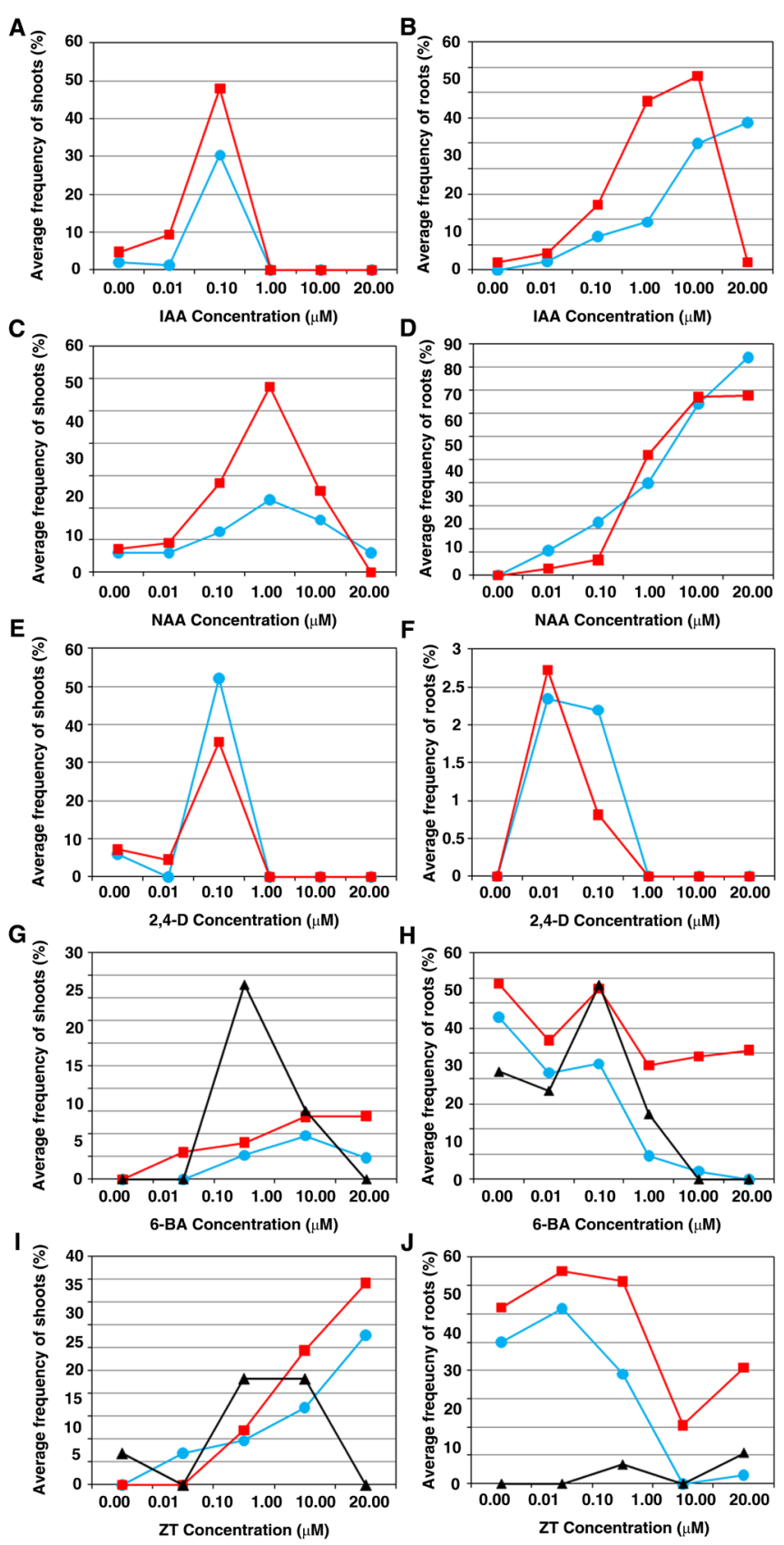

Figure 3. Auxin and cytokinin concentration ranges for effective adventitious shoot or root regeneration. Effective concentration ranges of IAA (A), NAA (C) and 2,4-D (E) for shoot regeneration; of IAA (B), NAA (D) and 2,4-D (F) for root regeneration; of 6-BA (G) and ZT (I) for shoot regeneration; and of 6-BA (H) and ZT (J) for root regeneration. The shoot or root regeneration frequency is the average of regeneration observed at six cytokinin concentrations $(0.00,0.01,0.10,1.00$, 10.00 , and $20.00 \mu \mathrm{M}$ ) with a defined auxin concentration (A-F). The shoot or root regeneration frequency is the average of regeneration observed at six auxin concentrations $(0.00,0.01,0.10,1.00,10.00$, and $20.00 \mu \mathrm{M})$ with a defined cytokinin concentration $(\mathrm{G})-(\mathrm{J})$. The blue solid circles in $(\mathrm{A})-(\mathrm{F})$ represent that variable adventitious shoot or root regeneration efficiencies for leaf explants treated with 6-BA in combination with three auxins. The red solid rectangles in (A)-(F) represent that variable adventitious shoot or root regeneration efficiencies for leaf explants treated with ZT in combination with three auxins. The blue solid circles in (G)-(J) represent that variable adventitious shoot or root regeneration efficiencies for leaf explants treated with IAA in combination with two cytokinins. The re solid rectangles in (G)-(J) represent that variable adventitious shoot or root regeneration efficiencies for leaf explants treated with NAA in combination with two cytokinins. The black solid triangles in $(G)-(J)$ represent that variable adventitious shoot or root regeneration efficiencies for leaf explants treated with 2,4-D in combination with two cytokinins. 
cytokinin concentrations (Figures 2(G)-(L)). The ZT-treated leaf explants that had undergone a reduced induction period generated a higher rate of organogenesis than did the 6-BA-treated leaf explants (Figures 2(A)-(F)). These results indicate that the natural cytokinin ZT might be more efficient than the synthetic cytokinin 6-BA in triggering Arabidopsis leaf explant-derived shoot initiation.

\section{Acknowledgements}

This research is supported by grants from the National Natural Science Foundation of China (90917015, 31000652) and the Ministry of Science and Technology (MOST) of China (2007CB948200).

\section{References}

[1] Pulianmackal, A.J., Kareem, A.V., Durgaprasad, K., Trivedi, Z.B. and Prasad, K. (2014) Competence and Regulatory Interactions during Regeneration in Plants. Frontiers in Plant Science, 11, 142.

http://dx.doi.org/10.3389/fpls.2014.00142

[2] Ikeda-Iwai, M., Satoh, S. and Kamada, H. (2002) Establishment of a Reproducible Tissue Culture System for the Induction of Arabidopsis Somatic Embryos. Journal of Experimental Botany, 53, 1575-1580. http://dx.doi.org/10.1093/jxb/erf006

[3] Kim, J.S., Lee, S.Y., Eom, S.H. and Park, S.U. (2010) Improved Shoot Organogenesis and Plant Regeneration of Echinacea angustifolia DC. Journal of Medicinal Plants Research, 4, 587-591.

[4] Kolar, A.B., Vivekanandan, L. and Basha, M.G. (2008) In Vitro Regeneration and Flower Induction on Solanum nigrum L. from Pachamalai Hills of Eastern Ghats. Plant Tissue Culture and Biotechnology, 18, 43-48. http://dx.doi.org/10.3329/ptcb.v18i1.3264

[5] Lü, J., Chen, R., Zhang, M., da Silva, J.A. and Ma, G. (2013) Plant Regeneration via Somatic Embryogenesis and Shoot Organogenesis from Immature Cotyledons of Camellia nitidissima Chi. Journal of Plant Physiology, 170, 12021211. http://dx.doi.org/10.1016/j.jplph.2013.03.019

[6] Naing, A.H., Jeon, S.M., Han, J.S., Lim, S.H., Lim, K.B. and Kim, C.K. (2014) Factors Influencing in Vitro Shoot Regeneration from Leaf Segments of Chrysanthemum. Comptes Rendus Biologies, 337, 383-90. http://dx.doi.org/10.1016/j.crvi.2014.03.005

[7] Salehi, M., Hosseini, B. and Jabbarzadeh, Z. (2014) High-frequency in vitro plantlet regeneration from apical bud as a novel explant of Carum copticum L. Asian Pacific Journal of Tropic Biomedicine, 4, S424-428. http://dx.doi.org/10.12980/APJTB.4.2014C529

[8] Wu, B.H., Zheng, Y.L., Liu, D.C., Zhou, Y.H. and Yan, Z.H. (2003) Unisexual Pistillate Flower Regeneration in Immature Embryo Culture of Wheat. Acta Botanica Sinica, 45, 452-459.

[9] Sugiyama, M. (2000) Genetic Analysis of Plant Morphogenesis in Vitro. International Review of Cytology, 196, 67-84.

[10] Azad, M.A.K., Yokota, S., Yahara, S. and Yoshizawa, N. (2004) Effects of Explant Type and Growth Regulators on Organogenesis in a Medicinal Tree, Phellodendron amurense Rupr. Asian Journal of Plant Sciences, 3, 522-528. http://dx.doi.org/10.3923/ajps.2004.522.528

[11] Can, E., Çeliktaş, N. and Hatipoğlu, R. (2008) Effect of Auxin Type and Concentrations in Different Media on the Callus Induction and Shoot Formation of Crested Wheatgrass (Agropyron cristatum (L.) Gaertn). Biotechnology \& Biotechnological Equipment, 22, 782-786.

[12] Candela, M., Velâzquez, I., De La Cruz, B., Sendino, A.M. and De La Peña, A. (2001) Differences in in Vitro Plant Regeneration Ability among Four Arabidopsis thaliana Ecotypes. In Vitro Cellular \& Development Biology-Plant, 37, 638-643.

[13] Chakravarthi, D.V.N., Indukuri, V., Goparaju, U.A. and Yechuri, V. (2010) Effect of Genotype, Explant and Hormonal Concentration on in Vitro Response of Eggplant. Notulae Scientia Biologicae, 2, 77-85.

[14] Kamal, G.B., Illich, K.G. and Asadollah, A. (2007) Effects of Genotype, Explant Type and Nutrient Medium Components on Canola (Brassica napus L.) Shoot in Vitro Organogenesis. Africa Journal of Biotechnology, 6, 861-867.

[15] Michel, Z., Hilaire, K.T., Mongomaké, K., Georges, A.N. and Justin, K.Y. (2008) Effect of Genotype, Explants Growth Regulators and Sugars on Callus Induction in Cotton (Gossypium hirsutum L.). Australian Journal of Crop Science, 2, 1-9.

[16] Phelan, S., Hunter, A. and Douglas, G.C. (2009) Effect of Expalnts Source on Shoot Proliferation and Adventitious Regeneration in 10 Buddleia Cultivars. Scientia Horticulturae, 120, 518-524. http://dx.doi.org/10.1016/j.scienta.2008.11.009

[17] Su, Y.H. and Zhang, X.S. (2014) The Hormonal Control of Regeneration in Plants. Current Topic in Developmental 
Biology, 108, 35-69. http://dx.doi.org/10.1016/B978-0-12-391498-9.00010-3

[18] Subotić, A., Jevremović, S. and Grubišić, D. (2009) Influence of Cytokinins on in Vitro Morphogenesis in Root Cultures of Centaurium erythraea-Valuable Medicinal Plant. Scientia Horticulturae, 120, 386-390. http://dx.doi.org/10.1016/j.scienta.2008.11.034

[19] Christianson, M.L. and Warnick, D.A. (1985) Temporal Requirement for Phytohormone Balance in the Control of Organogenesis in Vitro. Developmental Biology, 112, 494-497.

[20] Su, Y.H., Liu, Y.B. and Zhang, X.S. (2011) Auxin-Cytokinin Interaction Regulates Meristem Development. Molecular Plant, 4, 616-625. http://dx.doi.org/10.1093/mp/ssr007

[21] Gu, X.F. and Zhang, J.R. (2005) An Efficient Adventitious Shoot Regeneration System for Zhanhua Winter Jujube (Zizyphus jujube Mill.) Using Leaf Explants. Plant Cell Reports, 23, 775-779.

[22] Li, Q., Deng, M., Zhang, J., Zhao, W., Song, Y., Li, Q. and Huang, Q. (2013) Shoot Organogenesis and Plant Regeneration from Leaf Explants of Lysionotus serratus D. Don. Scientific World Journal, 2013, Article ID: 280384. http://dx.doi.org/10.1155/2013/280384

[23] Raghu, A.V., Geetha, S.P., Martin, G., Balachandran, I. and Ravindran, P.N. (2006) Direct Shoot Organogenesis from Leaf Explants of Embelia ribes Burm. f.: A Vulnerable Medicinal Plant. Journal of Forest Research, 11, 57-60. http://dx.doi.org/10.1007/s10310-005-0188-1

[24] Tilkat, E. and Onay, A. (2009) Direct Shoot Organogenesis from in Vitro-Derived Mature Leaf Explants of Pistachio. In Vitro Cellular \& Developmental Biology-Plant, 45, 92-98. http://dx.doi.org/10.1007/s11627-008-9168-4

[25] Sahoo, S. and Rout, G.R. (2014) Plant Regeneration from Leaf Explants of Aloe barbadensis Mill. and Genetic Fidelity Assessment through DNA Markers. Physiology and Molecular Biology of Plants, 20, 235-240. http://dx.doi.org/10.1007/s12298-014-0226-6

[26] Landi, L. and Mezzetti, B. (2006) TDZ, Auxin and Genotype Effects on Leaf Organogenesis in Fragaria. Plant Cell Reports, 25, 281-288.

[27] Tsugawa, H., Kagami, T. and Suzuki, M. (2004) High-Frequency Transformation of Lobelia erinus L. by Agrobacterium-Mediated Gene Transfer. Plant Cell Reports, 26, 1263-1273.

[28] Vogel, G. (2005) How Does a Single Somatic Cell Become a Whole Plant. Science, 309, 86.

[29] Zhao, X.Y., Su, Y.H., Zhang, C.L., Wang, L., Li, X.G. and Zhang, X.S. (2013) Differences in Capacities of in Vitro Organ Regeneration between Two Arabidopsis Ecotypes Wassilewskija and Columbia. Plant Cell, Tissue and Organ Culture, 112, 65-74. http://dx.doi.org/10.1007/s11240-012-0216-8

[30] Murashige, T. and Skoog, F. (1962) A Revised Medium for Rapid Growth and Bioassays with Tobacco Tissue Cultures. Physiologia Plantarum, 15, 473-497.

[31] Kantia, A. and Kothari, S.L. (2002) High Efficiency Adventitious Shoot Bud Formation and Plant Regeneration from Leaf Explants of Dianthus chinensis L. Scientia Horticulturae, 96, 205-212.

[32] Pandey, V., Misra, P., Chaturvedi, P., Mishra, M.K., Trivedi, P.K. and Tuli, R. (2010) Agrobacterium tumefaciens-Mediated Transformation of Withania somnifera (L.) Dunal: An Important Medicinal Plant. Plant Cell Reports, 29, 133-141. http://dx.doi.org/10.1007/s00299-009-0805-0

[33] Ludwig-Müller, J., Vertocnik, A. and Town, C.D. (2005) Analysis of Indole-3-Butyric Acid-Induced Adventitious Root Formation on Arabidopsis Stem Segments. Journal of Experimental Botany, 56, 2095-2105.

[34] Mercier, H., Souza, B.M., Kraus, J.E., Hamasaki, R.M. and Sotta, B. (2003) Endogenous Auxin and Cytokinin Contents Associated with Shoot Formation in Leaves of Pineapple Cultured in Vitro. Brazilian Journal of Plant Physiology, 15, 107-112. http://dx.doi.org/10.1590/S1677-04202003000200006

[35] George, F.E., Hall, M.A. and De Klerk, G.J. (2008) Plant Propagation by Tissue Culture. 3nd Edition, Springer, Dordrecht. 


\section{Supplementary Tables}

Table S1. Combinations of auxin and cytokinin. There is 36 combniations between each type of auxins and each type of cytokinins, such as, IAA+6-BA, IAA+ZT, NAA+6-BA, NAA+6-BA, 2,4-D+6-BA, 2,4-D+ZT. Two hundred and sixteen hormones combinations were designed in all. ${ }^{*}$ Two numbers shown in brackets represents auxin concentration (the former) and cytokinin concentration (the latter), respectively.

\begin{tabular}{cccccccc}
\hline & & \multicolumn{7}{c}{$\begin{array}{c}\text { Cytokinin } \\
\text { 6-BA or ZT }(\boldsymbol{\mu} \mathbf{M})\end{array}$} \\
\cline { 3 - 8 } & & $\mathbf{0 . 0 0}$ & $\mathbf{0 . 0 1}$ & $\mathbf{0 . 1 0}$ & $\mathbf{1 . 0 0}$ & $\mathbf{1 0 . 0 0}$ & $\mathbf{2 0 . 0 0}$ \\
\hline & $\mathbf{0 . 0 0}$ & $(0.00,0.00)^{*}$ & $(0.00,0.01)$ & $(0.00,0.10)$ & $(0.00,1.00)$ & $(0.00,10.00)$ & $(0.00,20.00)$ \\
& $\mathbf{0 . 0 1}$ & $(0.01,0.00)$ & $(0.01,0.01)$ & $(0.01,0.10)$ & $(0.00,1.00)$ & $(0.01,10.00)$ & $(0.01,20.00)$ \\
$\begin{array}{c}\text { Auxin } \\
\text { IAA or NAA or 2,4-D } \\
(\boldsymbol{\mu M M )}\end{array}$ & $\mathbf{0 . 1 0}$ & $(0.10,0.00)$ & $(0.10,0.01)$ & $(0.10,0.10)$ & $(0.00,1.00)$ & $(0.10,10.00)$ & $(0.10,20.00)$ \\
& $\mathbf{1 . 0 0}$ & $(1.00,0.00)$ & $(1.00,0.01)$ & $(1.00,0.10)$ & $(0.00,1.00)$ & $(1.00,10.00)$ & $(1.00,20.00)$ \\
& $\mathbf{1 0 . 0 0}$ & $(10.00,0.00)$ & $(10.00,0.01)$ & $(10.00,0.10)$ & $(10.00,1.00)$ & $(10.00,10.00)$ & $(10.00,20.00)$ \\
& $\mathbf{2 0 . 0 0}$ & $(20.00,0.00)$ & $(20.00,0.01)$ & $(20.00,0.10)$ & $(20.00,1.00)$ & $(20.00,10.00)$ & $(20.00,20.00)$ \\
\hline
\end{tabular}

Table S2. Mean frequency of leaf explant-derived organogenesis following incubation with various concentrations and combinations of auxins and cytokinins.

\begin{tabular}{|c|c|c|c|c|c|c|}
\hline \multicolumn{2}{|c|}{ Exogenous Hormones } & \multicolumn{5}{|c|}{ Organ Regeneration Frequency (\%) } \\
\hline $\begin{array}{l}\text { Combination } \\
\text { (Auxin/CK) }\end{array}$ & $\begin{array}{c}\text { Concentration } \\
(\mu \mathrm{M})\end{array}$ & Calli & $\begin{array}{l}\text { Adventitious } \\
\text { Shoots }\end{array}$ & Inflorescences & $\begin{array}{c}\text { Leaf-Like } \\
\text { Organs }\end{array}$ & Adventitious Roots \\
\hline 2,4-D/6-BA & $0.00 / 0.00$ & 0.00 & 0.00 & 0.00 & 0.00 & 0.00 \\
\hline 2,4-D/6-BA & $0.00 / 0.01$ & 0.00 & 0.00 & 0.00 & 0.00 & 0.00 \\
\hline 2,4-D/6-BA & $0.00 / 0.10$ & 0.00 & 0.00 & 0.00 & 0.00 & 0.00 \\
\hline $2,4-\mathrm{D} / 6-\mathrm{BA}$ & $0.00 / 1.00$ & $21.55 \pm 2.46$ & $6.76 \pm 1.52$ & 0.00 & 0.00 & 0.00 \\
\hline 2,4-D/6-BA & $0.00 / 10.00$ & $31.57 \pm 1.54$ & $5.38 \pm 1.69$ & 0.00 & 0.00 & 0.00 \\
\hline 2,4-D/6-BA & $0.00 / 20.00$ & $31.64 \pm 1.98$ & 0.00 & 0.00 & 0.00 & 0.00 \\
\hline 2,4-D/6-BA & $0.01 / 0.00$ & $75.70 \pm 2.59$ & 0.00 & 0.00 & 0.00 & $54.55 \pm 4.52$ \\
\hline 2,4-D/6-BA & $0.01 / 0.01$ & $70.62 \pm 1.24$ & 0.00 & 0.00 & 0.00 & $35.32 \pm 1.35$ \\
\hline 2,4-D/6-BA & $0.01 / 0.10$ & $87.90 \pm 3.26$ & 0.00 & 0.00 & 0.00 & $66.77 \pm 3.54$ \\
\hline 2,4-D/6-BA & $0.01 / 1.00$ & $46.34 \pm 2.57$ & 0.00 & 0.00 & 0.00 & $31.39 \pm 1.30$ \\
\hline 2,4-D/6-BA & $0.01 / 10.00$ & $33.30 \pm 3.36$ & 0.00 & 0.00 & 0.00 & 0.00 \\
\hline 2,4-D/6-BA & $0.01 / 20.00$ & $2.95 \pm 1.20$ & 0.00 & 0.00 & 0.00 & 0.00 \\
\hline 2,4-D/6-BA & $0.10 / 0.00$ & $37.64 \pm 5.34$ & 0.00 & 0.00 & 0.00 & $31.38 \pm 2.30$ \\
\hline 2,4-D/6-BA & $0.10 / 0.01$ & $76.56 \pm 1.49$ & 0.00 & 0.00 & 0.00 & $35.35 \pm 3.52$ \\
\hline 2,4-D/6-BA & $0.10 / 0.10$ & $91.16 \pm 3.65$ & $10.30 \pm 1.35$ & $2.92 \pm 0.32$ & 0.00 & $88.25 \pm 5.34$ \\
\hline 2,4-D/6-BA & $0.10 / 1.00$ & 100.00 & $79.35 \pm 4.32$ & 0.00 & $7.85 \pm 0.75$ & $20.07 \pm 2.10$ \\
\hline 2,4-D/6-BA & $0.10 / 10.00$ & $56.38 \pm 3.54$ & $81.25 \pm 7.02$ & 0.00 & $5.20 \pm 1.31$ & 0.00 \\
\hline 2,4-D/6-BA & $0.10 / 20.00$ & $18.44 \pm 2.54$ & 0.00 & $55.30 \pm 2.65$ & 0.00 & 0.00 \\
\hline 2,4-D/6-BA & $1.00 / 0.00$ & 100.00 & 0.00 & 0.00 & 0.00 & 0.00 \\
\hline 2,4-D/6-BA & $1.00 / 0.01$ & $97.25 \pm 1.48$ & 0.00 & 0.00 & 0.00 & 0.00 \\
\hline 2,4-D/6-BA & $1.00 / 0.10$ & 100.00 & 0.00 & 0.00 & 0.00 & 0.00 \\
\hline
\end{tabular}




\section{Continued}

\begin{tabular}{|c|c|c|c|c|c|c|}
\hline 2,4-D/6-BA & $1.00 / 1.00$ & 100.00 & 0.00 & 0.00 & 0.00 & 0.00 \\
\hline 2,4-D/6-BA & $1.00 / 10.00$ & $93.88 \pm 3.56$ & 0.00 & 0.00 & 0.00 & 0.00 \\
\hline 2,4-D/6-BA & $1.00 / 20.00$ & $97.28 \pm 2.54$ & 0.00 & 0.00 & 0.00 & 0.00 \\
\hline 2,4-D/6-BA & $10.00 / 0.00$ & 100.00 & 0.00 & 0.00 & 0.00 & 0.00 \\
\hline 2,4-D/6-BA & $10.00 / 0.01$ & 100.00 & 0.00 & 0.00 & 0.00 & 0.00 \\
\hline 2,4-D/6-BA & $10.00 / 0.10$ & $97.29 \pm 2.43$ & 0.00 & 0.00 & 0.00 & 0.00 \\
\hline 2,4-D/6-BA & $10.00 / 1.00$ & 100.00 & 0.00 & 0.00 & 0.00 & 0.00 \\
\hline 2,4-D/6-BA & $10.00 / 10.00$ & 100.00 & 0.00 & 0.00 & 0.00 & 0.00 \\
\hline 2,4-D/6-BA & $10.00 / 20.00$ & 100.00 & 0.00 & 0.00 & 0.00 & 0.00 \\
\hline 2,4-D/6-BA & $20.00 / 0.00$ & 100.00 & 0.00 & 0.00 & 0.00 & 0.00 \\
\hline 2,4-D/6-BA & $20.00 / 0.01$ & $86.18 \pm 1.64$ & 0.00 & 0.00 & 0.00 & 0.00 \\
\hline 2,4-D/6-BA & $20.00 / 0.10$ & $48.58 \pm 2.54$ & 0.00 & 0.00 & 0.00 & 0.00 \\
\hline 2,4-D/6-BA & $20.00 / 1.00$ & $96.85 \pm 1.59$ & 0.00 & 0.00 & 0.00 & 0.00 \\
\hline 2,4-D/6-BA & $20.00 / 10.00$ & 100.00 & 0.00 & 0.00 & 0.00 & 0.00 \\
\hline 2,4-D/6-BA & $20.00 / 20.00$ & $91.79 \pm 1.63$ & 0.00 & 0.00 & 0.00 & 0.00 \\
\hline 2,4-D/ZT & $0.00 / 0.00$ & 0.00 & 0.00 & 0.00 & 0.00 & 0.00 \\
\hline 2,4-D/ZT & $0.00 / 0.01$ & $50.00 \pm 2.15$ & 0.00 & 0.00 & 0.00 & $3.33 \pm 2.35$ \\
\hline 2,4-D/ZT & $0.00 / 0.10$ & $50.80 \pm 2.45$ & 0.00 & 0.00 & 0.00 & 0.00 \\
\hline 2,4-D/ZT & $0.00 / 1.00$ & $58.65 \pm 1.58$ & $6.90 \pm 2.96$ & 0.00 & $4.52 \pm 1.03$ & $3.45 \pm 2.03$ \\
\hline 2,4-D/ZT & $0.00 / 10.00$ & $85.71 \pm 4.23$ & $7.14 \pm 2.41$ & 0.00 & $4.69 \pm 1.54$ & 0.00 \\
\hline 2,4-D/ZT & $0.00 / 20.00$ & $88.25 \pm 1.62$ & $14.29 \pm 1.65$ & 0.00 & $5.21 \pm 2.01$ & 0.00 \\
\hline 2,4-D/ZT & $0.01 / 0.00$ & $75.58 \pm 0.87$ & 0.00 & 0.00 & 0.00 & $54.50 \pm 2.51$ \\
\hline 2,4-D/ZT & $0.01 / 0.01$ & $25.52 \pm 2.31$ & 0.00 & 0.00 & 0.00 & 0.00 \\
\hline 2,4-D/ZT & $0.01 / 0.10$ & $23.53 \pm 3.54$ & 0.00 & 0.00 & 0.00 & 0.00 \\
\hline 2,4-D/ZT & $0.01 / 1.00$ & $43.75 \pm 2.46$ & $3.00 \pm 0.36$ & 0.00 & 0.00 & $6.25 \pm 1.03$ \\
\hline 2,4-D/ZT & $0.01 / 10.00$ & $53.85 \pm 2.78$ & $30.77 \pm 1.65$ & 0.00 & $8.26 \pm 1.05$ & 0.00 \\
\hline 2,4-D/ZT & $0.01 / 20.00$ & $86.11 \pm 4.18$ & $22.22 \pm 4.35$ & 0.00 & $7.56 \pm 1.54$ & 0.00 \\
\hline 2,4-D/ZT & $0.10 / 0.00$ & $90.91 \pm 5.14$ & 0.00 & 0.00 & 0.00 & $42.42 \pm 4.01$ \\
\hline 2,4-D/ZT & $0.10 / 0.01$ & $40.00 \pm 4.35$ & $6.98 \pm 1.25$ & 0.00 & 0.00 & $8.57 \pm 1.58$ \\
\hline 2,4-D/ZT & $0.10 / 0.10$ & 100.00 & $15.70 \pm 0.38$ & 0.00 & 0.00 & $43.33 \pm 3.26$ \\
\hline 2,4-D/ZT & $0.10 / 1.00$ & $96.67 \pm 2.65$ & $90.60 \pm 4.36$ & 0.00 & $11.02 \pm 1.33$ & $6.67 \pm 2.52$ \\
\hline 2,4-D/ZT & $0.10 / 10.00$ & $93.75 \pm 1.54$ & $91.30 \pm 5.70$ & 0.00 & $9.78 \pm 2.45$ & 0.00 \\
\hline 2,4-D/ZT & $0.10 / 20.00$ & 100.00 & $82.60 \pm 5.06$ & 0.00 & $3.58 \pm 0.65$ & $10.81 \pm 4.36$ \\
\hline 2,4-D/ZT & $1.00 / 0.00$ & 100.00 & 0.00 & 0.00 & 0.00 & 0.00 \\
\hline 2,4-D/ZT & $1.00 / 0.01$ & $91.45 \pm 4.25$ & 0.00 & 0.00 & 0.00 & 0.00 \\
\hline 2,4-D/ZT & $1.00 / 0.10$ & 100.00 & 0.00 & 0.00 & 0.00 & 0.00 \\
\hline 2,4-D/ZT & $1.00 / 1.00$ & 100.00 & 0.00 & 0.00 & 0.00 & 0.00 \\
\hline
\end{tabular}




\section{Continued}

\begin{tabular}{|c|c|c|c|c|c|c|}
\hline 2,4-D/ZT & $1.00 / 10.00$ & 100.00 & 0.00 & 0.00 & 0.00 & 0.00 \\
\hline 2,4-D/ZT & $1.00 / 20.00$ & 100.00 & 0.00 & 0.00 & 0.00 & 0.00 \\
\hline 2,4-D/ZT & $10.00 / 0.00$ & 100.00 & 0.00 & 0.00 & 0.00 & 0.00 \\
\hline 2,4-D/ZT & $10.00 / 0.01$ & $94.15 \pm 2.85$ & 0.00 & 0.00 & 0.00 & 0.00 \\
\hline 2,4-D/ZT & $10.00 / 0.10$ & 100.00 & 0.00 & 0.00 & 0.00 & 0.00 \\
\hline 2,4-D/ZT & $10.00 / 1.00$ & $96.96 \pm 3.26$ & 0.00 & 0.00 & 0.00 & 0.00 \\
\hline 2,4-D/ZT & $10.00 / 10.00$ & 100.00 & 0.00 & 0.00 & 0.00 & 0.00 \\
\hline 2,4-D/ZT & $10.00 / 20.00$ & 100.00 & 0.00 & 0.00 & 0.00 & 0.00 \\
\hline 2,4-D/ZT & $20.00 / 0.00$ & $95.88 \pm 1.25$ & 0.00 & 0.00 & 0.00 & 0.00 \\
\hline 2,4-D/ZT & 20.00/0.01 & $87.55 \pm 4.32$ & 0.00 & 0.00 & 0.00 & 0.00 \\
\hline 2,4-D/ZT & $20.00 / 0.10$ & 100.00 & 0.00 & 0.00 & 0.00 & 0.00 \\
\hline 2,4-D/ZT & $20.00 / 1.00$ & $91.47 \pm 1.58$ & 0.00 & 0.00 & 0.00 & 0.00 \\
\hline 2,4-D/ZT & $20.00 / 10.00$ & 100.00 & 0.00 & 0.00 & 0.00 & 0.00 \\
\hline 2,4-D/ZT & $20.00 / 20.00$ & 100.00 & 0.00 & 0.00 & 0.00 & 0.00 \\
\hline IAA/6-BA & $0.00 / 0.00$ & 0.00 & 0.00 & 0.00 & 0.00 & 0.00 \\
\hline IAA/6-BA & $0.00 / 0.01$ & 0.00 & 0.00 & 0.00 & 0.00 & 0.00 \\
\hline IAA/6-BA & $0.00 / 0.10$ & 0.00 & 0.00 & 0.00 & 0.00 & 0.00 \\
\hline IAA/6-BA & $0.00 / 1.00$ & $20.00 \pm 2.97$ & $6.77 \pm 1.29$ & 0.00 & $6.75 \pm 4.31$ & 0.00 \\
\hline IAA/6-BA & $0.00 / 10.00$ & $31.65 \pm 3.65$ & $5.35 \pm 1.54$ & 0.00 & $5.34 \pm 2.56$ & 0.00 \\
\hline IAA/6-BA & $0.00 / 20.00$ & $30.00 \pm 2.65$ & 0.00 & 0.00 & 0.00 & 0.00 \\
\hline IAA/6-BA & $0.01 / 0.00$ & $5.62 \pm 1.35$ & 0.00 & 0.00 & 0.00 & 0.00 \\
\hline IAA/6-BA & $0.01 / 0.01$ & $3.24 \pm 2.11$ & 0.00 & 0.00 & 0.00 & $3.23 \pm 2.67$ \\
\hline IAA/6-BA & $0.01 / 0.10$ & $3.32 \pm 2.30$ & 0.00 & 0.00 & 0.00 & $3.35 \pm 2.58$ \\
\hline IAA/6-BA & $0.01 / 1.00$ & $8.63 \pm 2.01$ & 0.00 & 0.00 & 0.00 & 0.00 \\
\hline IAA/6-BA & $0.01 / 10.00$ & $21.91 \pm 2.35$ & $13.15 \pm 0.69$ & 0.00 & $1.50 \pm 0.54$ & 0.00 \\
\hline IAA/6-BA & $0.01 / 20.00$ & $50.00 \pm 2.41$ & $3.12 \pm 0.32$ & 0.00 & $2.16 \pm 0.63$ & 0.00 \\
\hline IAA/6-BA & $0.10 / 0.00$ & 0.00 & 0.00 & 0.00 & 0.00 & 0.00 \\
\hline IAA/6-BA & $0.10 / 0.01$ & $3.40 \pm 0.67$ & 0.00 & 0.00 & 0.00 & 0.00 \\
\hline IAA/6-BA & $0.10 / 0.10$ & $5.00 \pm 0.54$ & 0.00 & 0.00 & 0.00 & 0.00 \\
\hline IAA/6-BA & $0.10 / 1.00$ & $13.34 \pm 2.34$ & 0.00 & 0.00 & 0.00 & $13.35 \pm 1.63$ \\
\hline IAA/6-BA & $0.10 / 10.00$ & $33.40 \pm 1.25$ & $19.71 \pm 1.65$ & 0.00 & $4.21 \pm 1.03$ & 0.00 \\
\hline IAA/6-BA & $0.10 / 20.00$ & $60.00 \pm 2.65$ & $3.32 \pm 0.25$ & 0.00 & $2.25 \pm 0.58$ & 0.00 \\
\hline IAA/6-BA & $1.00 / 0.00$ & $53.31 \pm 2.54$ & 0.00 & 0.00 & 0.00 & $53.30 \pm 4.20$ \\
\hline IAA/6-BA & $1.00 / 0.01$ & $25.84 \pm 0.64$ & 0.00 & 0.00 & 0.00 & $16.10 \pm 0.96$ \\
\hline IAA/6-BA & $1.00 / 0.10$ & $3.25 \pm 0.58$ & 0.00 & 0.00 & 0.00 & $3.20 \pm 2.14$ \\
\hline IAA/6-BA & $1.00 / 1.00$ & $6.89 \pm 1.32$ & $3.80 \pm 0.63$ & 0.00 & $3.10 \pm 1.12$ & $3.08 \pm 1.65$ \\
\hline
\end{tabular}




\section{Continued}

\begin{tabular}{|c|c|c|c|c|c|c|}
\hline IAA/6-BA & $1.00 / 10.00$ & $60.67 \pm 2.58$ & $6.10 \pm 2.12$ & 0.00 & $6.16 \pm 1.45$ & 0.00 \\
\hline IAA/6-BA & $1.00 / 20.00$ & $64.38 \pm 1.45$ & 0.00 & 0.00 & 0.00 & 0.00 \\
\hline IAA/6-BA & $10.00 / 0.00$ & $47.19 \pm 1.58$ & 0.00 & 0.00 & 0.00 & $47.18 \pm 5.98$ \\
\hline IAA/6-BA & $10.00 / 0.01$ & $62.95 \pm 2.34$ & 0.00 & 0.00 & 0.00 & $62.97 \pm 3.45$ \\
\hline IAA/6-BA & $10.00 / 0.10$ & $86.79 \pm 1.25$ & 0.00 & 0.00 & 0.00 & $86.78 \pm 1.54$ \\
\hline IAA/6-BA & $10.00 / 1.00$ & $66.80 \pm 2.58$ & $15.36 \pm 3.15$ & 0.00 & $12.5 \pm 2.75$ & $3.01 \pm 0.68$ \\
\hline IAA/6-BA & $10.00 / 10.00$ & $64.90 \pm 3.62$ & $13.57 \pm 2.10$ & 0.00 & $10.35 \pm 2.05$ & 0.00 \\
\hline IAA/6-BA & $10.00 / 20.00$ & $70.34 \pm 1.54$ & 0.00 & 0.00 & 0.00 & 0.00 \\
\hline IAA/6-BA & $20.00 / 0.00$ & $93.31 \pm 1.35$ & 0.00 & 0.00 & 0.00 & $93.34 \pm 2.74$ \\
\hline IAA/6-BA & 20.00/0.01 & $87.15 \pm 0.35$ & 0.00 & 0.00 & 0.00 & $87.15 \pm 2.51$ \\
\hline IAA/6-BA & $20.00 / 0.10$ & $90.38 \pm 0.85$ & 0.00 & 0.00 & 0.00 & $90.38 \pm 3.46$ \\
\hline IAA/6-BA & $20.00 / 1.00$ & $99.95 \pm 0.04$ & 0.00 & 0.00 & $15.74 \pm 0.86$ & $17.64 \pm 1.42$ \\
\hline IAA/6-BA & $20.00 / 10.00$ & $93.58 \pm 2.36$ & 0.00 & 0.00 & $7.62 \pm 0.54$ & $3.24 \pm 0.56$ \\
\hline IAA/6-BA & $20.00 / 20.00$ & $93.56 \pm 2.54$ & 0.00 & 0.00 & $2.56 \pm 1.35$ & 0.00 \\
\hline IAA/ZT & $0.00 / 0.00$ & 0.00 & 0.00 & 0.00 & 0.00 & 0.00 \\
\hline IAA/ZT & $0.00 / 0.01$ & $50.00 \pm 1.48$ & 0.00 & 0.00 & 0.00 & $3.33 \pm 2.65$ \\
\hline IAA/ZT & $0.00 / 0.10$ & $58.62 \pm 2.35$ & 0.00 & 0.00 & 0.00 & 0.00 \\
\hline IAA/ZT & $0.00 / 1.00$ & $75.00 \pm 1.24$ & 0.00 & 0.00 & 0.00 & $3.45 \pm 3.21$ \\
\hline IAA/ZT & $0.00 / 10.00$ & 100.00 & $7.17 \pm 1.36$ & 0.00 & 0.00 & 0.00 \\
\hline $\mathrm{IAA} / \mathrm{ZT}$ & $0.00 / 20.00$ & $91.30 \pm 3.51$ & 0.00 & 0.00 & 0.00 & $3.16 \pm 2.58$ \\
\hline IAA/ZT & $0.01 / 0.00$ & $5.60 \pm 2.45$ & 0.00 & 0.00 & 0.00 & 0.00 \\
\hline IAA/ZT & $0.01 / 0.01$ & $27.90 \pm 1.45$ & 0.00 & 0.00 & 0.00 & $6.56 \pm 2.51$ \\
\hline IAA/ZT & $0.01 / 0.10$ & $50.0 \pm 2.36$ & 0.00 & 0.00 & 0.00 & $3.13 \pm 3.01$ \\
\hline $\mathrm{IAA} / \mathrm{ZT}$ & $0.01 / 1.00$ & $80.00 \pm 4.32$ & $9.75 \pm 2.41$ & 0.00 & 0.00 & 0.00 \\
\hline IAA/ZT & $0.01 / 10.00$ & $96.55 \pm 1.35$ & $12.96 \pm 2.83$ & 0.00 & 0.00 & 0.00 \\
\hline IAA/ZT & $0.01 / 20.00$ & $88.89 \pm 5.60$ & $21.93 \pm 1.75$ & 0.00 & $5.82 \pm 1.36$ & 0.00 \\
\hline IAA/ZT & $0.10 / 0.00$ & $32.14 \pm 2.54$ & 0.00 & 0.00 & 0.00 & $53.35 \pm 2.98$ \\
\hline IAA/ZT & $0.10 / 0.01$ & $66.67 \pm 1.55$ & 0.00 & 0.00 & 0.00 & $17.25 \pm 2.45$ \\
\hline IAA/ZT & $0.10 / 0.10$ & $72.41 \pm 3.58$ & 0.00 & 0.00 & 0.00 & $6.38 \pm 1.56$ \\
\hline IAA/ZT & $0.10 / 1.00$ & $80.85 \pm 4.65$ & 0.00 & 0.00 & 0.00 & 0.00 \\
\hline IAA/ZT & $0.10 / 10.00$ & $68.75 \pm 1.75$ & $12.19 \pm 2.67$ & 0.00 & $5.62 \pm 2.31$ & 0.00 \\
\hline IAA/ZT & $0.10 / 20.00$ & $66.67 \pm 2.85$ & $23.38 \pm 3.46$ & 0.00 & $4.85 \pm 1.52$ & 0.00 \\
\hline IAA/ZT & $1.00 / 0.00$ & $47.19 \pm 2.45$ & 0.00 & 0.00 & 0.00 & $47.18 \pm 1.50$ \\
\hline IAA/ZT & $1.00 / 0.01$ & $80.05 \pm 3.69$ & 0.00 & 0.00 & 0.00 & $80.05 \pm 3.48$ \\
\hline IAA/ZT & $1.00 / 0.10$ & $99.47 \pm 1.85$ & 0.00 & 0.00 & 0.00 & $93.15 \pm 2.76$ \\
\hline IAA/ZT & $1.00 / 1.00$ & $33.39 \pm 1.45$ & 0.00 & 0.00 & 0.00 & $46.45 \pm 2.55$ \\
\hline
\end{tabular}




\section{Continued}

\begin{tabular}{|c|c|c|c|c|c|c|}
\hline IAA/ZT & $1.00 / 10.00$ & $40.58 \pm 2.35$ & $11.92 \pm 2.04$ & 0.00 & $7.20 \pm 2.98$ & 0.00 \\
\hline IAA/ZT & $1.00 / 20.00$ & 100.00 & $34.30 \pm 4.31$ & 0.00 & $5.24 \pm 2.50$ & 0.00 \\
\hline IAA/ZT & $10.00 / 0.00$ & $93.3 \pm 1.24$ & 0.00 & 0.00 & 0.00 & $93.36 \pm 1.20$ \\
\hline IAA/ZT & $10.00 / 0.01$ & $99.91 \pm 0.05$ & 0.00 & 0.00 & 0.00 & $96.65 \pm 0.86$ \\
\hline IAA/ZT & $10.00 / 0.10$ & $92.95 \pm 2.61$ & $6.98 \pm 0.65$ & 0.00 & 0.00 & $86.00 \pm 1.02$ \\
\hline IAA/ZT & $10.00 / 1.00$ & $88.20 \pm 2.53$ & $10.78 \pm 1.35$ & $3.68 \pm 0.87$ & 0.00 & $31.05 \pm 1.32$ \\
\hline IAA/ZT & $10.00 / 10.00$ & $85.74 \pm 2.37$ & $50.05 \pm 2.85$ & 0.00 & $12.57 \pm 1.53$ & 0.00 \\
\hline IAA/ZT & $10.00 / 20.00$ & $95.85 \pm 1.42$ & $62.56 \pm 3.42$ & 0.00 & $21.22 \pm 4.02$ & 0.00 \\
\hline IAA/ZT & $20.00 / 0.00$ & $83.87 \pm 1.85$ & 0.00 & 0.00 & 0.00 & $83.87 \pm 4.25$ \\
\hline IAA/ZT & $20.00 / 0.01$ & $89.29 \pm 1.54$ & 0.00 & 0.00 & 0.00 & $71.43 \pm 3.62$ \\
\hline IAA/ZT & $20.00 / 0.10$ & $83.87 \pm 1.58$ & 0.00 & 0.00 & 0.00 & $64.52 \pm 5.32$ \\
\hline IAA/ZT & $20.00 / 1.00$ & $87.10 \pm 1.62$ & $8.35 \pm 2.15$ & 0.00 & $15.76 \pm 1.17$ & $22.58 \pm 4.21$ \\
\hline IAA/ZT & $20.00 / 10.00$ & $93.10 \pm 1.40$ & $7.28 \pm 1.34$ & $3.47 \pm 5.30$ & $4.01 \pm 2.08$ & 0.00 \\
\hline IAA/ZT & $20.00 / 20.00$ & $92.59 \pm 2.36$ & $21.47 \pm 2.34$ & 0.00 & $7.18 \pm 1.62$ & $3.15 \pm 2.39$ \\
\hline NAA/6-BA & $0.00 / 0.00$ & 0.00 & 0.00 & 0.00 & 0.00 & 0.00 \\
\hline NAA/6-BA & $0.00 / 0.01$ & $25.75 \pm 2.15$ & 0.00 & 0.00 & 0.00 & 0.00 \\
\hline NAA/6-BA & $0.00 / 0.10$ & $18.75 \pm 1.45$ & 0.00 & 0.00 & 0.00 & 0.00 \\
\hline NAA/6-BA & $0.00 / 1.00$ & $85.71 \pm 2.31$ & $6.75 \pm 2.31$ & 0.00 & 0.00 & 0.00 \\
\hline NAA/6-BA & $0.00 / 10.00$ & $75.86 \pm 1.42$ & $5.37 \pm 1.36$ & 0.00 & 0.00 & 0.00 \\
\hline NAA/6-BA & $0.00 / 20.00$ & $75.96 \pm 1.35$ & 0.00 & 0.00 & 0.00 & 0.00 \\
\hline NAA/6-BA & $0.01 / 0.00$ & 0.00 & 0.00 & 0.00 & 0.00 & 0.00 \\
\hline NAA/6-BA & $0.01 / 0.01$ & $17.86 \pm 2.04$ & 0.00 & 0.00 & 0.00 & $7.17 \pm 1.58$ \\
\hline NAA/6-BA & $0.01 / 0.10$ & $47.06 \pm 1.34$ & $5.95 \pm 2.14$ & 0.00 & 0.00 & 0.00 \\
\hline NAA/6-BA & $0.01 / 1.00$ & $42.86 \pm 2.15$ & 0.00 & 0.00 & 0.00 & $14.34 \pm 1.14$ \\
\hline NAA/6-BA & $0.01 / 10.00$ & $51.52 \pm 1.24$ & $9.10 \pm 2.04$ & 0.00 & $2.31 \pm 1.63$ & 0.00 \\
\hline NAA/6-BA & $0.01 / 20.00$ & $51.61 \pm 2.45$ & $3.20 \pm 1.32$ & 0.00 & 0.00 & 0.00 \\
\hline NAA/6-BA & $0.10 / 0.00$ & $26.83 \pm 1.35$ & 0.00 & 0.00 & 0.00 & 0.00 \\
\hline NAA/6-BA & $0.10 / 0.01$ & $92.65 \pm 0.95$ & 0.00 & 0.00 & 0.00 & $37.00 \pm 4.35$ \\
\hline NAA/6-BA & $0.10 / 0.10$ & $77.59 \pm 1.57$ & 0.00 & 0.00 & 0.00 & $19.40 \pm 2.15$ \\
\hline NAA/6-BA & $0.10 / 1.00$ & $56.41 \pm 2.34$ & 0.00 & 0.00 & 0.00 & $12.00 \pm 2.63$ \\
\hline NAA/6-BA & $0.10 / 10.00$ & $93.87 \pm 1.63$ & $12.50 \pm 1.25$ & 0.00 & 0.00 & 0.00 \\
\hline NAA/6-BA & $0.10 / 20.00$ & $61.36 \pm 0.96$ & 0.00 & 0.00 & 0.00 & 0.00 \\
\hline NAA/6-BA & $1.00 / 0.00$ & $70.73 \pm 1.54$ & 0.00 & 0.00 & 0.00 & $46.75 \pm 1.45$ \\
\hline NAA/6-BA & $1.00 / 0.01$ & $81.37 \pm 1.42$ & 0.00 & 0.00 & 0.00 & $50.08 \pm 1.24$ \\
\hline NAA/6-BA & $1.00 / 0.10$ & $86.76 \pm 1.36$ & 0.00 & 0.00 & 0.00 & $86.70 \pm 2.31$ \\
\hline NAA/6-BA & $1.00 / 1.00$ & $67.84 \pm 2.54$ & $10.75 \pm 1.36$ & 0.00 & 0.00 & $32.10 \pm 2.12$ \\
\hline
\end{tabular}




\section{Continued}

\begin{tabular}{|c|c|c|c|c|c|c|}
\hline NAA/6-BA & $1.00 / 10.00$ & $89.39 \pm 1.43$ & $35.78 \pm 2.54$ & 0.00 & $2.58 \pm 0.63$ & $3.65 \pm 1.20$ \\
\hline NAA/6-BA & $1.00 / 20.00$ & $94.45 \pm 1.35$ & $20.67 \pm 1.43$ & 0.00 & $2.35 \pm 0.85$ & $20.65 \pm 2.46$ \\
\hline NAA/6-BA & $10.00 / 0.00$ & $92.97 \pm 1.59$ & 0.00 & 0.00 & 0.00 & $92.98 \pm 2.01$ \\
\hline NAA/6-BA & $10.00 / 0.01$ & $90.53 \pm 1.54$ & 0.00 & 0.00 & 0.00 & $90.05 \pm 1.84$ \\
\hline NAA/6-BA & $10.00 / 0.10$ & 100.00 & 0.00 & 0.00 & 0.00 & 100.00 \\
\hline NAA/6-BA & $10.00 / 1.00$ & $80.00 \pm 2.35$ & 0.00 & 0.00 & 0.00 & $80.98 \pm 5.62$ \\
\hline NAA/6-BA & $10.00 / 10.00$ & $57.24 \pm 1.24$ & $14.35 \pm 1.42$ & 0.00 & $3.45 \pm 0.78$ & $42.95 \pm 4.85$ \\
\hline NAA/6-BA & $10.00 / 20.00$ & $92.99 \pm 1.85$ & $17.97 \pm 1.79$ & 0.00 & $7.28 \pm 0.80$ & $39.34 \pm 3.67$ \\
\hline NAA/6-BA & $20.00 / 0.00$ & $94.10 \pm 1.24$ & 0.00 & $5.85 \pm 2.01$ & 0.00 & $94.17 \pm 2.35$ \\
\hline NAA/6-BA & $20.00 / 0.01$ & $92.24 \pm 1.35$ & 0.00 & 0.00 & 0.00 & $92.29 \pm 3.24$ \\
\hline NAA/6-BA & $20.00 / 0.10$ & $97.04 \pm 2.04$ & 0.00 & 0.00 & 0.00 & $97.07 \pm 2.11$ \\
\hline NAA/6-BA & $20.00 / 1.00$ & $94.25 \pm 1.25$ & $6.72 \pm 3.21$ & 0.00 & 0.00 & $87.58 \pm 3.45$ \\
\hline NAA/6-BA & $20.00 / 10.00$ & 100.00 & $5.39 \pm 1.35$ & $25.8 \pm 2.31$ & 0.00 & 100.00 \\
\hline NAA/6-BA & $20.00 / 20.00$ & $94.19 \pm 2.91$ & 0.00 & 0.00 & 0.00 & $94.15 \pm 4.75$ \\
\hline NAA/ZT & $0.00 / 0.00$ & 0.00 & 0.00 & 0.00 & 0.00 & 0.00 \\
\hline NAA/ZT & $0.00 / 0.01$ & $50.00 \pm 4.10$ & 0.00 & 0.00 & 0.00 & 0.00 \\
\hline NAA/ZT & $0.00 / 0.10$ & $37.55 \pm 0.55$ & 0.00 & 0.00 & 0.00 & 0.00 \\
\hline NAA/ZT & $0.00 / 1.00$ & $75.69 \pm 1.69$ & 0.00 & 0.00 & 0.00 & 0.00 \\
\hline NAA/ZT & $0.00 / 10.00$ & 100.00 & $7.12 \pm 1.37$ & 0.00 & 0.00 & 0.00 \\
\hline NAA/ZT & $0.00 / 20.00$ & $88.25 \pm 052$ & 0.00 & 0.00 & 0.00 & 0.00 \\
\hline NAA/ZT & $0.01 / 0.00$ & $36.42 \pm 1.24$ & 0.00 & 0.00 & 0.00 & 0.00 \\
\hline NAA/ZT & $0.01 / 0.01$ & $41.67 \pm 0.68$ & 0.00 & 0.00 & 0.00 & $2.93 \pm 2.05$ \\
\hline NAA/ZT & $0.01 / 0.10$ & $60.65 \pm 1.65$ & 0.00 & 0.00 & 0.00 & 0.00 \\
\hline NAA/ZT & $0.01 / 1.00$ & $80.98 \pm 1.89$ & $8.68 \pm 0.86$ & 0.00 & 0.00 & 0.00 \\
\hline NAA/ZT & $0.01 / 10.00$ & $81.35 \pm 1.35$ & $9.47 \pm 0.54$ & 0.00 & 0.00 & 0.00 \\
\hline NAA/ZT & $0.01 / 20.00$ & 100.00 & 0.00 & 0.00 & 0.00 & 0.00 \\
\hline NAA/ZT & $0.10 / 0.00$ & $31.36 \pm 1.91$ & 0.00 & 0.00 & 0.00 & $6.35 \pm 1.32$ \\
\hline NAA/ZT & $0.10 / 0.01$ & $35.29 \pm 1.08$ & 0.00 & 0.00 & 0.00 & $14.38 \pm 1.22$ \\
\hline NAA/ZT & $0.10 / 0.10$ & $54.37 \pm 4.32$ & 0.00 & 0.00 & 0.00 & $2.99 \pm 0.85$ \\
\hline NAA/ZT & $0.10 / 1.00$ & $93.33 \pm 5.20$ & 0.00 & $3.00 \pm 1.52$ & 0.00 & 0.00 \\
\hline NAA/ZT & $0.10 / 10.00$ & $93.89 \pm 1.47$ & $28.10 \pm 1.28$ & 0.00 & $7.38 \pm 1.56$ & $3.14 \pm 2.56$ \\
\hline NAA/ZT & $0.10 / 20.00$ & $94.45 \pm 7.20$ & $27.31 \pm 1.62$ & 0.00 & $8.60 \pm 1.28$ & 0.00 \\
\hline NAA/ZT & $1.00 / 0.00$ & $46.76 \pm 4.18$ & 0.00 & 0.00 & 0.00 & $46.79 \pm 2.52$ \\
\hline NAA/ZT & $1.00 / 0.01$ & $96.87 \pm 4.25$ & 0.00 & 0.00 & 0.00 & $96.85 \pm 2.20$ \\
\hline NAA/ZT & $1.00 / 0.10$ & 100.00 & 0.00 & 0.00 & 0.00 & 100.00 \\
\hline NAA/ZT & $1.00 / 1.00$ & $60.78 \pm 1.35$ & $15.24 \pm 1.63$ & 0.00 & $2.58 \pm 1.15$ & $45.55 \pm 3.25$ \\
\hline
\end{tabular}




\begin{tabular}{ccccccc} 
Continued & \multicolumn{1}{c}{ (100.00 } & $80.00 \pm 4.58$ & 0.00 & $18.51 \pm 1.36$ & $16.79 \pm 1.54$ \\
\hline NAA/ZT & $1.00 / 10.00$ & $77.40 \pm 1.65$ & 0.00 & $20.11 \pm 1.85$ & $6.57 \pm 2.06$ \\
NAA/ZT & $1.00 / 20.00$ & $83.96 \pm 4.78$ & 0.00 & 0.00 & 0.00 & $92.98 \pm 3.55$ \\
NAA/ZT & $10.00 / 0.00$ & $92.94 \pm 1.25$ & 0.00 & 0.00 & 0.00 & 100.00 \\
NAA/ZT & $10.00 / 0.01$ & 100.00 & 0.00 & 0.00 & 0.00 & $97.02 \pm 2.80$ \\
NAA/ZT & $10.00 / 0.10$ & $97.25 \pm 4.25$ & 0.00 & 0.00 & 0.00 & $68.88 \pm 4.51$ \\
NAA/ZT & $10.00 / 1.00$ & $68.84 \pm 2.53$ & 0.00 & $10.12 \pm 1.65$ & $48.45 \pm 2.30$ \\
NAA/ZT & $10.00 / 10.00$ & $71.33 \pm 6.35$ & $22.60 \pm 1.26$ & 0.00 & 5.00 & $55.66 \pm 3.31$ \\
NAA/ZT & $10.00 / 20.00$ & $83.45 \pm 1.42$ & $27.85 \pm 3.45$ & 0.00 & $94.19 \pm 2.56$ \\
NAA/ZT & $20.00 / 0.00$ & $94.17 \pm 5.32$ & 0.00 & $5.85 \pm 2.60$ & 0.00 & $96.76 \pm 3.12$ \\
NAA/ZT & $20.00 / 0.01$ & $96.75 \pm 2.69$ & 0.00 & 0.00 & 0.00 & 100.00 \\
NAA/ZT & $20.00 / 0.10$ & 100.00 & 0.00 & 0.00 & 0.00 & 100.00 \\
NAA/ZT & $20.00 / 1.00$ & 100.00 & 0.00 & 0.00 & 0.00 & $84.35 \pm 3.01$ \\
NAA/ZT & $20.00 / 10.00$ & 100.00 & 0.00 & 0.00 & 0.00 & $60.77 \pm 2.34$ \\
NAA/ZT & $20.00 / 20.00$ & $60.74 \pm 1.35$ & 0.00 & 0.00 & 0.00 & \\
\hline
\end{tabular}


Scientific Research Publishing (SCIRP) is one of the largest Open Access journal publishers. It is currently publishing more than 200 open access, online, peer-reviewed journals covering a wide range of academic disciplines. SCIRP serves the worldwide academic communities and contributes to the progress and application of science with its publication.

Other selected journals from SCIRP are listed as below. Submit your manuscript to us via either submit@scirp.org or Online Submission Portal.
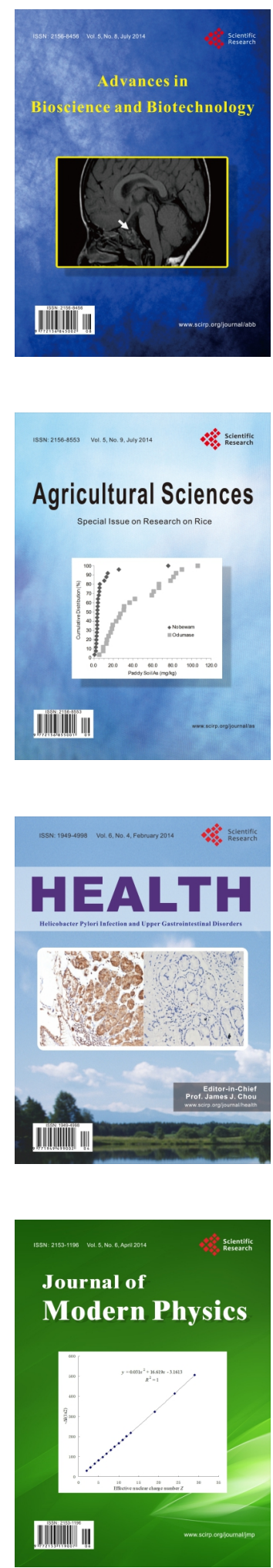
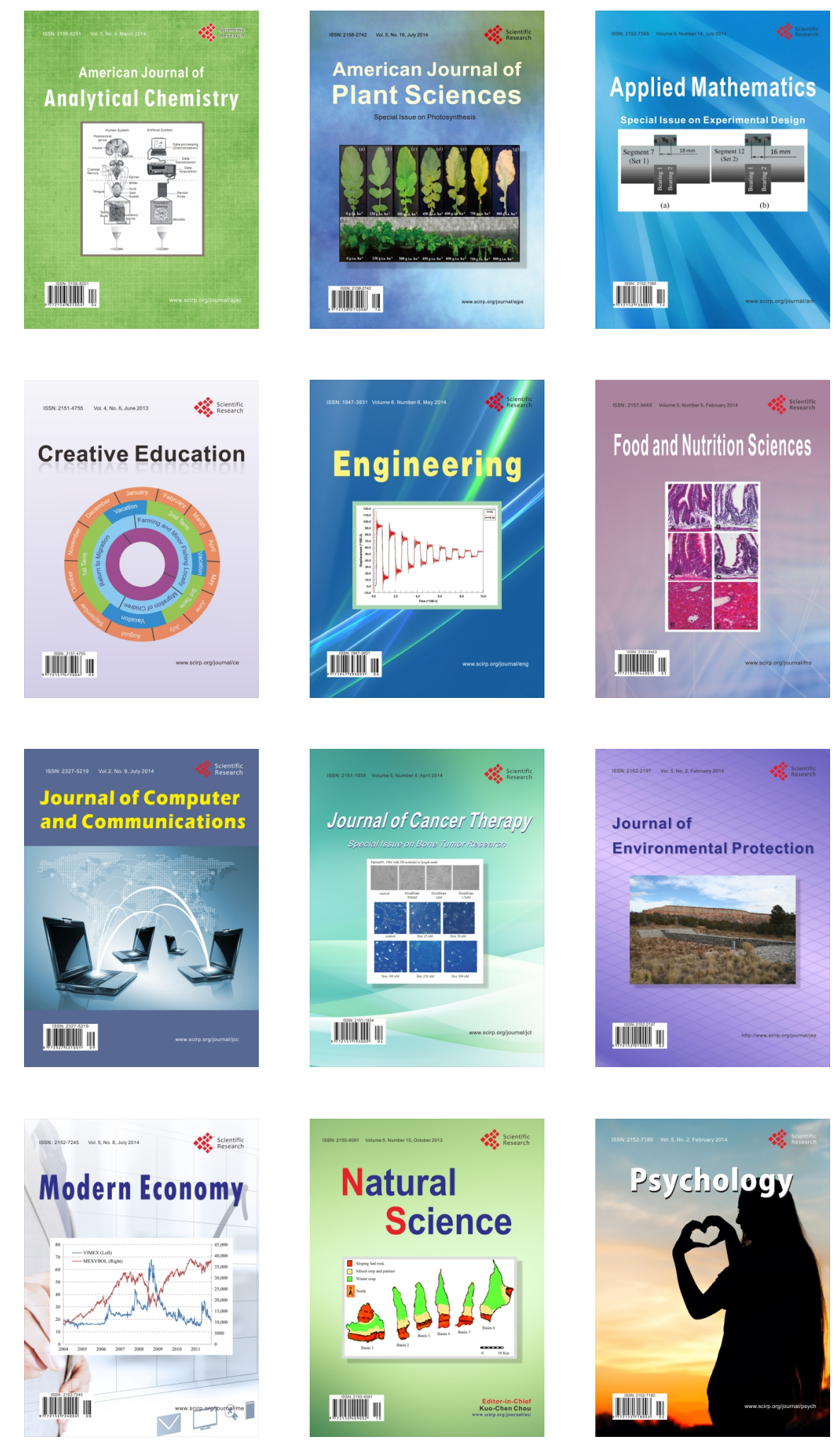